\title{
Societal Value Antecedent of Corporate Social Responsibility and Business Strategy
}

\author{
Kwaku Ahenkora ${ }^{1}$, Stephen Banahene ${ }^{1} \&$ Joyce Quartey $^{1}$ \\ ${ }^{1}$ School of Business, Christian Service University College, Kumasi, Ghana \\ Correspondence: Kwaku Ahenkora, School of Business, Christian Service University College, PO Box 3110, \\ Kumasi, Ghana. E-mail: k.ahenkora@yahoo.co.uk
}

Received: September 30, 2013

Accepted: October 24, $2013 \quad$ Online Published: November 9, 2013

doi:10.5430/jms.v4n4p58

URL: http://dx.doi.org/10.5430/jms.v4n4p58

\begin{abstract}
The characterisation and justification of corporate social responsibility (CSR) actions have left unexplored the antecedents of CSR such as societal values. In this study, using Vodafone Ghana, we explore the role of societal values in business and corporate social responsibility. Societal views, expressed in local philosophical thoughts, showed the expectations on business to uphold both the profit motive and sharing of gains with society. Community connection and stakeholder perspectives are central to Vodafone's CSR initiatives and business strategy. Thus, mainstreaming of CSR follows the syncretic stewardship model as the company embraces economic objectives as well as virtue. The societal value antecedent, therefore, has implication for the model of CSR that is adopted to achieve the business' strategic objectives. It also adds to the integrative social contract theory by making explicit aspects of the implicit social contract that exists in the relationship between business and society.
\end{abstract}

Keywords: corporate social responsibility, societal values, qualitative, business strategy, syncretic stewardship model, social contract theory

\section{Introduction}

Corporate social responsibility is an important dimension of contemporary business activities (Kotler and Keller 2008) and has moved from ideology to reality. It has become necessary for organisations to define their roles in society and apply social and ethical standards to their businesses (Lichtenstein et al., 2004). Implementation of CSR in organisations may be done through either incremental or transformational organisational change processes (Dunphy et al., 2003) or by radical, transformational approaches in which managers rethink their prevailing views about strategy, technology and markets (Doppelt, 2003). That business enterprises should take on some social responsibilities apart from making profits for shareholders has been with the business world for centuries. Practical emphasis on its imperatives, however, dates back to the past half century, so that now, as Carroll and Shabana, (2010) observe, one cannot pick up a newspaper, magazine or journal without finding some discussion of the issue, some recent or innovative example of what business is thinking or doing about CSR, or some new conference that is being held. For example, CSR centres, journals, non-governmental organisations and awards inundate the developing economy landscape. In its evolution CSR has spawned off several theories and various conceptualisations.

The theories that have influenced the domain include agency theory, institutional theory, the resource-based view of the firm, stakeholder theory, stewardship theory and the theory of the firm (McWilliams et. al., 2002). Lee (2008) argued that conceptualizations of and research of CSR has evolved along two avenues; in terms of the level of analysis research has moved from macro social effects to organisational-level analysis of CSR and its impact on organisational processes and performance. In terms of the theoretical orientation of the field, research has moved from explicitly normative and ethics-oriented arguments to implicitly normative and performance-oriented managerial studies. A recent brilliant review on corporate social responsibility by Lindgreen and Swaen (2010) provided insights into the conditions for successful CSR implementation and also reported additional research on CSR fields that remain under researched. One of such areas is the antecedents of CSR such as the societal level values. The fundamental question that emerges from viewpoints in this area is, how do societal values shape corporate response (Basu and Palazzo, 2008)? Additionally, what arguments inform corporate response?

This study, therefore, explores the role of societal values in corporate social responsibility and business strategy with a view to understanding how it is leveraged; that is how business integrates social demands in such a way that the 
business operates in accordance with social values. It considers the business and society relationship from the social contract tradition, including the philosophical thought of Locke and the integrative social contract theory of Donaldson and Dunfee (1994; 1999), which has an inbuilt assumption that a sort of an implicit social contract between business and society exists. But what are some of the implicit social values that are assumed in the integrative social contract theory? This study brings to the fore core societal values and philosophical thoughts on business and corporate social responsibility and thus adds some flesh to the theoretical macrosocial contract of the integrative social contract theory.

\section{Historical Background and Theoretical Perspectives}

In 1953, Bowen wrote the acclaimed seminal book outlining the social responsibilities of the businessman. In the 1950s the concept of social responsibility included the idea of the manager as public trustee and business' support of good causes. While this was gaining grounds, Levitt (1958) signaled a cautious note about business' new found love with social responsibility, arguing that social concerns and welfare were government's responsibility and not that of business. This notwithstanding, academics and businesses moved forward with research and practice in social responsibility. The 1960s and early 1970s have been described as the 'Awareness' and 'Issues' era of CSR and was characterised, for example, by community involvement, concern for racial discrimination and charitable donations by business. Other commentators made other characterizations in this period such as 'Quality of Life Management', which was silent about profit maximisation and trusteeship management (Hay and Gray, 1974) and 'Corporate Social Responsiveness' (Frederick, 2008), where response was altruistic without the profit motive. Frederick differentiated between corporate social responsibility and corporate social responsiveness, the former had companies assuming a socially responsible posture while the latter focused on the act of responding or of achieving a responsive posture towards society (Frederick, 1978). Corporate social performance, CSP, as a concept also emerged (Carroll, 1999). Frederick (2008) termed the 1980s as the beginning of the 'corporate/business ethics' stage where the focus was towards developing ethical corporate cultures. In the same period, academic research increased and there were attempts to link CSR with corporate financial performance (CFP). The 1990s and 2000s were characterized as the era of global corporate citizenship. However, the 2000s also witnessed the Enron scandal and the Wall Street Financial Scandal. Carroll and Shabana (2010) recount that though CSR continued to find business legitimacy, the emergence and preoccupation with business ethics obscured the continued growth and development of the social responsibility theme, except in the UK and continental Europe.

With the sketchy historical development above, we now outline some of the arguments for and against CSR before we provide theoretical propositions that have a bearing on our subject matter. Any concept that can be subjected to rigorous academic analysis and robust practical assessment, always attract two sides. As is the case for most fields of study that emerged in the last half century, CSR has attracted both positive and negative connotations. We will mention a few. Friedman (1962) was among the very first to write the case against CSR using classical economic arguments. He argued that management has one responsibility and that is to maximize the profits of its owners or shareholders and that they should leave social issues for government and legislations. Heyek (1969) extended this view by indicating that managers lose the business focus when they saddle themselves with social responsibility issues that pertain to fields of endeavour that is not related to their core aim. Business by pursuing CSR, therefore, makes itself globally less competitive. On the positive side, proponents argue that it is in business' long-term self-interest, that is enlightened self-interest, to be socially responsible by taking actions now that ensures its long-term viability. Today, more than ever, society warms up to the fact that in addition to profits, business should be responsible to their stakeholders, even if making things better comes at the cost of reducing profits (Bernstein 2000). Moreover, businesses today are inundated with requests from society, as part of normal fundraising initiatives in good times or rapid response to disaster in bad times. Why do businesses wait for such solicitations? Wouldn't business be better off, anticipating this as part of planned corporate giving?

We now turn our attention to some of the theoretical debates. Before then, a definition of CSR is appropriate. For academic purposes, Carroll's enduring quarter century definition is apt, and is stated as follows: 'The social responsibility of business encompasses the economic, legal, ethical, and discretionary [later referred to as philanthropic] expectations that society has of organisations at a given point in time' (Carroll 1979). The definition is useful and a good starting point to focus thinking for a growing field that is not short of theories, approaches and terminologies. Society and business, business ethics, social issues management, public policy and business, stakeholder management, corporate accountability are some of the terms that have been used to express the essence of CSR in its evolutionary development. Given the realization that the map of the field is quite poor (Carroll, 1994), attempts have been made towards clarification through classification. Frederick initiated the process when he outlined a classification based on a conceptual transition from the ethical-philosophical concept of CSR (i.e. CSR1), 
the action-oriented managerial concept of social responsiveness (CSR2), and the normative ethical and values view (CSR3), the normative element of the cosmos as the basic element of social issues in management and considers the role of science and religion in these issues (CSR4).

Garriga and Melé (2004), reviewed previous classifications and noting that the nature of the relationship between business and society is rarely situated at the centre, mapped the territory by classifying the main CSR theories and related approaches in four groups: (1) instrumental theories, in which the corporation is seen only as an instrument for wealth creation, and its social activities are only a means to achieve economic results: (2) political theories, which concern themselves with the power of corporations in society and a responsible use of power in the political arena; (3) integrative theories, in which the corporation is focused on the satisfaction of social demands; and (4) ethical theories, based on ethical responsibilities of corporations to society. According to the authors, in practice each CSR theory presents four dimensions related to profits, political performance, social demands and ethical values. Three areas of institutional theories were identified based on the economic objective: in the first group the objective is the maximization of shareholder value, measured by the share price. The second group of theories is relevant to this study and focuses on the strategic goal of achieving competitive advantages to produce long-term profits. CSR, in both cases, is a means of making profit, an enlightened self-interest. Three approaches have also been identified and they include social investments in competitive context, natural resource-based view of the firm and its dynamic capabilities and strategies for the bottom of the economic pyramid. It has been suggested that investing in philanthropic activities may be the only way to improve the context of competitive advantage of a firm and usually creates greater social value than individual donors or government can (Porter and Kramer, 2002). In other words, philanthropic investments by members of cluster, either individually or collectively, can have a powerful effect on cluster competitiveness and the performance of all its constituent companies. The third is related to cause-related marketing and is very close to the second.

In terms of relevance to our subject, of equal importance is the integrative social contract theory. Donaldson (1982) considered the business and society relationship from the social contract tradition, mainly from the philosophical thought of Locke. He assumed that a sort of implicit social contract between business and society exists. This social contract implies some indirect obligations of business towards society. Integrative theories are aimed at understanding how the dependence of business on society and the necessity for management to take on board and integrate social demands so that business operates in accordance with social values. Donaldson and Dunfee's Integrative Social Contract Theory (ISCT) accommodates the socio-cultural context and also integrate empirical and normative aspects of management (Donaldson and Dunfee, 2000). The authors assumed two levels of consent from which emerge social responsibility. Firstly, a theoretical macrosocial contract appealing to all rational contractors, and secondly, a real microsocial contract by members of numerous localized communities. The macrosocial contract provides rules for any social contracting; the 'hyper-norms' rules that take precedence over other contracts. They are so fundamental and basic they are discernible in a convergence of religious, political, and philosophical thought. The microsocial contracts show explicit or implicit agreements that are binding within an identified community, whatever this may be: industry, companies or economic systems. Social contract theory also underlies some theories on corporate citizenship as developed by Donaldson and Dunfee $(1994,1999)$. Although the academic consideration of "corporate citizen" or the related term "business citizen" is quite recent (Matten et al., 2003; Wood and Logsdon, 2002), it is clear to managers and business that business needs to take account the community where it is operating., business partnerships, which are the specific ways of formalizing the willingness to improve the local community and for consideration for the environment.

In highlighting gaps in knowledge, we note that the integrative social theory makes the fundamental assumption that there is an implicit social contract between business and society and implies some indirect obligations of business towards society. This points to the need to understand the social values that inform social contract; pertinently more so as the societal value antecedent is under researched. Furthermore, the content of business responsibility is limited to the space and time of each situation depending on the values of society at that moment (Preston and Post, 1975), suggesting that these theories are focused on the detection and scanning of, and response to, the social demands that achieve social legitimacy, greater social acceptance and prestige (Garriga and Melé, 2004). Garriga and Melé, (2004), have also called for the need to develop new theory on the business and society relationship which would integrate the four dimensions of profits, political performance, social demands and ethical values. Exploring and understanding corporate response in practice may throw some light to this pathway.

\section{Method}

A qualitative mode of enquiry, using semi-structured interview and discussions with members of the Ghana Employers Association (20 people) and recipients of Africa Foundation for Development (AFFORD), UK business support (25 
people), was used to obtain information on societal views on business, profit and corporate giving. The views were supplemented with information from the first Vodafone Stakeholders'Forum in which 70 stakeholders participated. The themes that emerged were crystallised into local philosophical thoughts and expressions that give meaning to them. Although, for the purpose of this paper, these expressions were captured using one of the local Ghanaian languages, Twi, similar expressions exist in other tongues, and they resonate with society at large. Secondary information was used to analyse Vodaphone Ghana's views on its business and corporate social responsibility (Vodaphone, 2013). Vodafone in Ghana is an operating company of Vodaphone Group plc, a leading mobile telecommunications company with presence in Europe, the Middle East, Africa, Asia Pacific and the United States. It acquired $70 \%$ shares in Ghana Telecommunications Company (GT) for \$900 million dollars in 2008.

\section{Results and Discussion}

\subsection{Societal Values}

While several views were made on the role of and attitudes towards business, the traditional Ghanaian view had a clear cut stand on business and profits which is expressed as:

'Mfaso nti na yedi dwa' (we do business to make profit)

The Ghanaian society and business people have a positive attitude towards the profit motive and the business bottom-line. However, this was in addition to other equally important perspectives about business. The first relates to the following concept:

$$
\text { 'ndwa nam', (game or booty). }
$$

The African custom of sharing has an application to business. It is customarily required to share game with neighbours on return from the farm. This practice is reminiscent of past traditional society when war booty was shared with the whole community. Now, implicit in this concept, in relation to business, is the notion that business must share its gains with society.

The following concepts also express the expectation of business' social contribution:

' $n s a$ ks na nsa aba, (one good turn deserves a favour) or

'dee syam aduhwam no smpepa ne nsa kwa',

These concepts suggest that once society accommodates and supports a business, it naturally expects to benefit from the business. Both the economic and philanthropic responsibilities of business are acknowledged and there is an expectation of corporate response. Corporate behaviour is one that is alleged by a stakeholder to be expected by society or morally required and is therefore justifiably demanded of business (Whetten et al., 2002).

\subsection{Corporate Social Responsibility}

The company discharges its social responsibility through responsible employee volunteerism, providing access to communication in deprived communities through the Vodafone Ghana Foundation. According to the company,

'Corporate responsibility is simply approaching our business aims responsibly with an awareness of our surrounding environmental needs in order to fulfill stakeholder demands, achieve profit and still remain competitive'.

For Vodafone, corporate responsibility in short is taking a fresh approach to objectives in order to reduce the environmental impact on business and to meet the needs of stakeholders, whilst maintaining a successful financial bottom line. By practicing greater responsibility the company intends to have a positive impact on the wider society. The company's CSR intent in Ghana covers the environment, stakeholder engagement, ethics and access to communications. It aims to reduce carbon emissions and ensure compliance with all environmental requirements by cutting down on energy use in offices. The company engages with stakeholders who it considers as people who can affect the business or who are affected by it, and this group includes employees, suppliers, non-governmental organizations (NGOs), government agencies, regulators and the communities within which it operates. It holds face to face discussion sessions, interviews and stakeholder forums twice every year and give feedback to them on issues raised. At the first Vodafone Stakeholders' Forum, the company indicated that:

'Our aim is to help key stakeholders better understand our activities and also to achieve a better corporate responsibility plan which will be implementable and easily adaptable.'

The company seeks to uphold the highest ethical standards in all business practices: responsible network deployment; responsible marketing; legal compliance, staff and stakeholder engagement and makes it mandatory for all senior staff to undertake anti-corruption training, an issue of national consideration. Additionally, the company seeks to 
make it possible for all people to have access to communication as well as lower tariffs for the disabled and elderly. Also through the Vodafone Foundation the company contributes to the national development agenda. The Foundation provides a formal process for charitable contributions to communities, community groups and Non Governmental Organisations (NGOs) in Ghana who are key partners in responding to social and economic development issues in the country. The Foundation is built on the philosophy that corporate bodies have a responsibility to give back to society.

\subsection{CSR and Business Success Linkages}

Vodafone Ghana prides itself as the only total communications solutions provider - mobile, fixed lines, internet, voice and data - and indicates that it is currently unmatched in providing fixed line and internet services - the leader and the first choice. It is also the second ranked operator in mobile with a huge potential to take over the market. According to Vodafone Ghana:

'Our goal is to be the communications leader in an increasingly connected world by providing innovative and responsive service.'

Ghana's Telecommunication industry is at the growth stage. Vodafone Ghana's strategic intent is to wrestle the leadership from MTN Ghana which is currently the leading operator in mobile. The company states clearly that its commitment to CSR is based on the fact that it is the right thing to do, it is good for business, stakeholders expect it and it meets regulation/legislation requirements. From the company's perspective:

"The work of the Foundation is an expression of our connection to the community in which we operate".

The company provides a strategic business perspective to CSR when it emphasises:

'We are sure that increasingly the success of our business will be based on the quality of our connection to community.'

Towards this strategic direction, the Foundation spreads support to as many projects and communities without compromising the company's direction and impact, innovates and develops best practice in the broader Social Investment agenda. Vodafone's approach collaborate views that the conditions for a successful CSR implementation clearly requires sensitivity to the norms and values of host communities, as well as open conversations with representatives from multiple communities (Lindgreen \& Swaen, 2010).

\subsection{Discussion}

The social values embedded in philosophical thoughts about the purpose of business above uncover the implicit social contract that exists in the relationship between business and society. Societal values on business, in its recognition of the profit motive as a goal of business, resonate with the Friedman view that emphasises profit as the business' concern. However, the business' social responsibility is recognised such that, the purpose of business is not necessarily only to make profit, but additionally, there is the expectation that business shares its gains with society. There are different propositions about the purpose of business and these align with the legal and socio-cultural contexts. Shareholder primacy holds that the legal purpose of the business run by its corporate executives is to make as much money as possible while conforming to the basic rule of society (Ehrlich, 2005). Blair and Stout's (1999) team production model accepts sacrificing profits in the social interest, as long as the profits are allocated to a deserving factor of production. Another view of the purpose of business is the "operational discretion" model, which holds that the law grants managers discretion to comply with social and moral norms, even if doing so reduces shareholder profits (Elhauge 2005). The "progressive view" proposes that business is organised for the benefit of society at large, or at the very least, business leaders have fiduciary responsibilities that extend to a wide variety of stakeholders, thus sacrificing profits in the public interest is entirely legal (Sheehy 2005: Gabaldon 2006). Garriga and Melé (2004) have suggested that concern of business for wealth creation is rooted in certain cultural values regarding the free market, private property and the fact that wealth creation is good for society. Social responsibility is not forced but comes by consent, and this suggests that the social values highlighted by this study can be treated as the macrosocial contract that provides rules- hyper norms, that take precedence over other norms.

Vodafone has internalised the CSR dimensions through its practical definition and application of CSR. Caroll (1979) developed a model of CSR based on the pyramid of responsibilities that include the economic, legal, ethical and philanthropic dimensions. CRS is an evolving concept that currently does not have a universally accepted definition in spite of several many (Carroll and Shabana, 2010, Dahlsrud, 2006). The EU Commission (2002) asserts that CSR is a concept whereby companies integrate social and environmental concerns in their business operations and in their interaction with their stakeholders on a voluntary basis. Inyang, Awa and Enuoh (2011) define CSR as "obligation of 
businessmen to pursue those policies, to make those decisions, to follow those lines of action, which are desirable in terms of objectives and values to the society of their location".

Vodafone's approach to implementation of CSR can be interpreted within the CSR mainstreaming rationales of Berger et al., (2007). The authors have suggested three rationales: social values-led model, the business-case model and the syncretic stewardship model. In the social values-led model, CSR is the organisation's lifeblood and is integrated to the organisational fibre in every way, thus CSR initiatives are not pre-empted by economic gains. However, in the business-case model, CSR initiatives are adjudged purely on economic merits and are pursued only when there is a link to the firm's financial performance. In the syncretic stewardship model, the firm is attuned to the external market for virtue while embracing economic objectives. Vodafone's approach thus follows the syncretic stewardship model as CSR is a management philosophy, an overarching approach to business. Vodafone acknowledges the complex relationship between CSR, firm performance and the interdependence of business and society. Vodafone's CSR practices and mainstreaming and their link to the firm's strategy shows that, not only does it pursue CSR in a way most appropriate to its strategy (Porter and Kramer, 2006), but it does so with an eye on competitive advantage. Connecting to the community is important for both the company's business success and towards achieving its goal of becoming the leader in the industry. The use of the syncretic stewardship model is a perfect response to societal and stakeholder expectations of business to make profit and share such gains with society.

\section{Conclusion}

The study concludes that the societal value antecedent, couched in local philosophical thoughts on the profit motive and virtue, has implication for the model of CSR that is adopted to achieve the business' strategic objectives and also makes explicit, aspects of the implicit social contract that exists in the relationship between business and society.

\section{References}

Basu, K., \& Palazzo, G. (2008). A process model of sensemaking. Academy of Management Review, 33, 122-136. http://dx.doi.org/10.5465/AMR.2008.27745504

Berger, I. E., Cunningham, P., \& Drumwright, M.E. (2007). Mainstreaming corporate social responsibility: developing markets for virtue. California Management Review, 49, 132-157. http://dx.doi.org/10.2307/41166409

Bernstein, A. (2000). Too much corporate power. Business Week, 11 September, p140.

Blair, M., M., \& Stout, L.A. (1999). A team production theory of corporate law. Virginia Law Review, 85, 247. http://dx.doi.org/10.2307/1073662

Bowen, H.R. (1953). Social Responsibilities of the Businessman. Harper \& Row: New York.

Carroll, A. B. (1979). A three dimensional conceptual model of corporate social performance. Academy of Management Review, 4, 497-505.

Carroll, A. B. (1994). Social issues in Management Research, Business and Society, 33(1), 5-25.

Carroll, A. B. (1999). Corporate Social Responsibility: evolution of a definitional construct. Business and Society, 38(3), 268-295. http://dx.doi.org/10.1177/000765039903800303

Carroll, A.B., \& Shabana, K.M. (2010). The business case for corporate social responsibility: a review of concepts, research and practice. International Journal of Management Reviews, 85-105. http://dx.doi.org/10.1111/j.1468-2370.2009.00275.x

Dahlsrud, A. (2006). How corporate social responsibility is defined: an analysis of 37 definitions. Corporate social responsibility and environmental management, September.

Donaldson, T. (1982). Corporations and Morality. Prentice Hall: Englewood Cliff, NJ.

Donaldson, T., \& Dunfee, T.W. (1994). Towards a unified conception of business ethics: integrative social contracts theory. Academy of Management Review, 19, 252-284.

Donaldson, T., \& Dunfee, T.W. (1999). Ties That Bond: a social contracts approach to business ethics. Harvard Business School Press: Boston.

Doppelt, B. (2003). Leading change toward sustainability. Sheffield: Greenleaf Publishing.

Dunphy, D., Griffiths, A., \& Benn, S. (2003). Organisational Change for Corporate Sustainability. London: Routledge.

Ehrlich, C. (2005). Is business ethics necessary? DePaul Business \& Commercial Law Journal, 4, 55. 
Elhauge, E. (2005). Corporate managers' operational discretion to sacrifice profits in the public interest. In H. Bruce, R. Stavins, \& R. Vietor (Eds.), Environmental Protection and the Social Responsibility of Firms. Washington DC: Resources for the Future.

European Union. (2002). Green paper promoting a European framework for corporate social responsibility. Brussels: European Commission.

Frederick, W.C. (2008). Corporate social responsibility: deep roots, flourishing growth, promising future. In Crane A., McWilliams, A., Matten, D., Moon, J., \& Siegel, D. (Eds.), The Oxford Handbook of Corporate Social Responsibility (pp 522-531). Oxford: Oxford University Press.

Friedman, M. (1962). The social responsibility of business is to increase its profits. New York Times, September, 126.

Gabaldon, T. (2006). Like a fish needs a bicycle: public corporations and their shareholders. Maryland Law Review, $65,538$.

Garriga, E., \& Melé, D. (2004). Corporate social responsibility theories: Mapping the Territory. Journal of Business Ethics, 53, 51-71. http://dx.doi.org/10.1023/B:BUSI.0000039399.90587.34

Hay, R., \& Gray, E. (1974, March). Social responsibilities of business managers. Academy of Management Journal, 135-143. http://dx.doi.org/10.2307/254777

Inyang, B.J. (2013). Defining the role engagement of small and medium-size enterprises (SMEs) in Corporate Social Responsibility (CSR). International business research, 6(5), 123-132.

Inyang, B.J., Awa, H.O., \& Enuoh, R.O. (2011). CSR-HRM nexus: defining the role engagement of the human resources professional. International Journal of Business and Social Sciences, 2(5), 118-126.

Kotler, P., \& Keller, M. (2008). Marketing management $13^{\text {th }}$ International Edition. London: Prentice Hall.

Lee, M.P. (2008). A review of the theories of corporate social responsibility: its evolutionary path and the road ahead. International Journal of Management Reviews, 10, 53-73. http://dx.doi.org/10.1111/j.1468-2370.2007.00226.x

Levitt, T. (1958, September-October). The dangers of social responsibility. Harvard Business Review, 41-50.

Lichtenstein, D.R., Drumwright, M.E., \& Braig, B.M. (2004). The effect of corporate social responsibility on customer donations to corporate-supported nonprofits. Journal of Marketing, 68, 16-32. http://dx.doi.org/10.1509/jmkg.68.4.16.42726

Lindgreen, A., \& Swaen, V. (2010). Corporate social responsibility. International Journal of Management Reviews, 1-5. http://dx.doi.org/10.1111/j.1468-2370.2009.00277.x

Matten, D., Crane, A., \& Chapple, W. (2003). Behind the mask: revealing the true face of corporate citizenship. Journal of Business Ethics, 45, 109-120. http://dx.doi.org/10.1023/A:1024128730308

McWilliams, A. Van Fleet, D.D., \& Cory, K. (2002). Raising rivals' costs through political strategy: an extension of the resource-based theory. Journal of Management Studies, 39, 707-723. http://dx.doi.org/10.1111/1467-6486.00308

Porter, M.E., \& Kramer, M.R. (2002). The competitive advantage of corporate philanthropy. Harvard Business Review, 80, 56-69.

Porter, M.E., \& Kramer, M.R. (2006). Strategy \& Society: The link between competitive advantage and corporate social responsibility. Harvard Business Review, 84, 78-92.

Preston, L. E., \& Post, J. E. (1975). Private Management and Public Policy, California Management Review, 23(3), 56-63. http://dx.doi.org/10.2307/41172602

Sheehy, B. (2005). Scrooge the reluctant stakeholder: Theoretical problems in shareholder-stakeholder debate. University of Miami Business Law Review, 14, 193.

$\begin{array}{lllll}\text { Vodaphone. } & \text { (2013). Retrieved } & \text { April, }\end{array}$ http://www.vodafone.com.gh/About-Us/Corporate-responsibility.aspx

Whetten, D.A., Rands, G., \& Godfrey, P. (2002). What are the responsibilities of business to society? In Pettigrew, A., Thomas, H., and Whittington, R. (Eds.), Handbook of Strategy and Management (pp.373-408). London: Sage.

Wood, D.J., \& Logsdon, J.M. (2002). Business Citizenship: From Individuals to Organisations. Business Ethics Quarterly, Ruffin Series, (3), 59-94. 